\title{
PERAN PEREMPUAN SHAHABIYAH DALAM PERIWAYATAN HADITS
}

\author{
Rabiatul Aslamiah \\ Fakultas Dakwah dan Ilmu Komunikasi, UIN Antasari, Banjarmasin, Indonesia \\ Email: rabiatulaslamiah@uin-antasari.ac.id
}

\begin{abstract}
Women in the early days of Islam were given the opportunity as given to mento gain knowledge. To them the Messenger of Allah taught science in the form of his traditions, and they were also permitted to narrate the hadith that they received to others. Women narrated traditions directly from the Prophet, or through friends, both male friends and female friends. The hadiths that they have narrated are many and quite varied, concerning issues of faith and Islam in general, the problem of muamalah, especially matters related to women's issues, family life and household.
\end{abstract}

KEYWORDS: Hadis; Women; Shahabiyah

\section{Pendahuluan}

Sejak 14 abad yang lalu, Islam telah menghapus berbagai macam diskriminasiantara laki-laki dan perempuan. Islam juga memberikan hak-hak kepada perempuan secara adil dan seimbang dengan hak-hak yang diberikan kepada laki-laki. Pada masa awal Islam (masa Rasulullah saw), selain kaum lakilaki, perempuan juga diberikan hak untuk menerima pendidikan dan pengajaran dari Rasulullah saw, yaitu berupa menghadiri majelis ta'lim yang dikhususkan bagi perempuan uantuk menerima pelajaran dari Rasulullah saw.

Pengajaran yang diberikan kepada perempuan tidak hanya terbatas pada majelis ta'lim itu, tetapi Rasulullah juga bersedia memberikan jawaban terhadap pertanyaan yang disampaikan oleh perempuan berkenaan dengan permasalahan yang mereka hadapi atau yang ingin mreka ketahui. Pertanyaan itu ada yang langsung disampaikan kepada Rasulullah oleh perempuan yang bersangkutan, dan ada yang disampaikan lewat seorang sahabat lainnya yang menyampaikannya kepada Rasulullah saw.

Para isteri Rasulullah saw, banyak menerima pelajaran, bimbingan dan nasehat dari Rasulullah saw. Mereka bergaul dan melihat secara langsung apa yang terjadi pada Rasulullah saw.sepanjang hidup beliau. Mereka menanyakan hal-hal yang belum mereka pahami, menyampaikan hal-hal yang mereka alami sekaligus mengetahui jawaban dan tanggapan Rasulullah saw terhadap masalah itu, dan bahkan mereka ada yang memberikan pendapat, usul dan saran kepada 
Rasulullah saw.

Para sahabat perempuan, dapat menerima pelajaran dan nasehat dari Rasulullah secara langsung dan dapat juga melalui isteri-isteri Rasulullah saw, mereka dapat bertanya kepada Rasulullah saw. secara langsung dan juga dapat bertanya melalui orang lain yang mereka minta, baik isteri Rasul saw ataupun para sahabat lainnya.

Semua yang diketahui oleh kaum perempuan shahabiyah yang berkaitan dengan Rasulullah saw menjadi pelajaran yang sangat berharga bagi ummat Islam, yang nantinya hal itu mereka sampaikan kepada orang lain, yang disebut meriwayatkan hadis Rasul saw. Pada tulisan ini akan dikemukakan secara sederhana tentang peran perempuan sahabat Rasulullah saw dalam periwayatan hadis- hadis Rasulullah saw.

\section{Kajian Teori}

\section{Periwayatan dan Pengajaran Hadis pada masa Rasulullah saw.}

Cara periwayatan dan pengajaran hadits pada masa Rasulullah saw. ada beberapa yaitu:

1. Pada majelis- majelis Rasulullah.

Rasulullah saw secara khusus mengadakan majelis yang berkaitan dengan pengajaran Islam, yang bertempat di masjid dan dirumah-rumah. Diantara majlis itu ada majlis yang khusus disediakan untuk kaum perempuan.

2. Pada peristiwa yang dialami oleh Rasulullah saw, kemudian Rasulullah saw menjelaskan tentang peristiwa tersebut.

3. Pada peristiwa yang dialami oleh kaum muslimin, lalu mereka menanyakan kepada Rasulullah saw.

4. Pada peristiwa yang disaksikan langsung oleh para sahabat, apa yang terjadi dan apa yang dilakukan Rasulullah.

Adapun cara periwayatan (menerima dan meriwayatkan) yang dilakukan sahabat pada masa rasulullah adalah:

1. Secara langsung.

Sahabat Rasulullah ada yang secara langsung mendengar, melihat atau menyaksikan tentang apa yang disabdakan, dilakukan, taqrir Rasulullah saw. Hal tersebut didapat dengan cara menghadiri majelis-majelis Rasulullah saw, mengajukan pertanyaan, berhubungan langsung dan menyertai Rasulullah saw. dalam kesehariannya.

2. Secara tidak langsung.

Diantara para sahabat Nabi saw, ada yang tidak mengetahui secara langsung dari Nabi saw,karena adanya halangan seperti: kesibukan mengurus keperluan keluarga, keperluan ekonomi dan kepeerluan lain, begitu juga karena tempat tinggal yang jauh dari tempat tinggal Nabi saw, atau merasa malu untuk bertanya 
langsung kepada Nabi saw, sehingga meminta orang lain untuk menanyakan tentang masalah yang mereka hadapi serta adanya perintah nabi kepada para sahabat dan isteri beliau agar menhampaikan ajaran Rasulullah saw kepada mereka yang tidak/ belum mengetahuinya.( Syuhudi Ismail 1991: 87)

\section{Hasil Penelitian dan Pembahasan \\ Sahabat Perempuan Perawi Hadis}

Kalau dibanding dengan perawi laki-laki, periwatan yang dilakukan oleh perempuan memang lebih kecil kuwantitasnya. Meskipun demikian, peran periwayat perempuan sangat besar ma'nanya dalam dalam kesempurnaan ajaran Rasulullah saw. Karena periwayat perempuan, disamping dapat meriwayatkan hadis yang sifatnya umum, seperti hal yang dilakukan sahabat laki-laki, juga meriwayatkan hadis yang sifatnya khusus itentang masalah perempuan, anakanak dan keluarga yang biasanya luput dari perhatian laki-laki. Khusus mengenai isteri-isteri Rasulullah saw, mereka dapat meriwayatkan hadis yang yang lebih spesifik mengenai keseharian Rasulullah saw di rumah tangganya, seperti mengenai tidur, mandi, wudhu, janabah, makan, minum dan juga perkataan dan sikap perilaku lainnya.

Sahabat perempuan yang meriwayatkan hadis dapat diklasifikasi menjadi dua kelompok yaitu:

\section{a) Ummahatul mu'minin (Isteri-isteri Rasulullah saw.)}

1. Aisyah

Aisyah binti Abu Bakr Al Siddiq ibn Abi Quhafah, ibunya bernama: Ummu Ruman binti Umayr dari Kinanah. Dia dilahirkan pada tahun keempat kenabian, dia dnikahi Rasulullah saw di Mekkah, dua tahun sebelum hijrah ke Madinah, saat dia berusia tujuh tahun, dan berkumpul dengan Rasulullah saw dua di Madinah yaitu pada bulan Syawal, setelah perang Badar yang kedua. Aisyah tinggal bersama Rasulullah saw selama delapan tahun lima bulan. Beliau wafat di Madinah pada masa pemerintahan Muawiyah bin Abi Sufyan, yaitu pada malam selasa tanggal 17 Ramadhan tahun $58 \mathrm{H}$, dengan usia 65 tahun.

Aisyah adalah tokoh utama dalam meriwayatkan hadis- hadis Nabi saw. Dia perempuan yang paling banyak meriwayatkan hadis Nabi saw.yaitu sebanyak 2210 hadist. Bukhari dan Muslim meriwayatkan sebanyak 316 hadis, dengan perincian: Yang disepakati Bukhari Muslim sebanyak 194 hadis, Bukhari saja sebanyak 54 hadis, Muslim saja sebanyak 68 buah hadis. Selebihnya tersebar pada kitab-kitab hadis lainnya. Dia meriwayatkan hadis secara langsung dari Rasulullah saw, dan juga dari Abu Bakar al Siddiq, Umar ibn Khattab, Hamzah, dan Fatimah Azzahra.

Orang-orang menerima hadits dari beliau terdiri dari berbagai kalangan:

1) Kalangan sahabat: Ayahanda beliau: Abu Bakar al Siddiq, Umar Ibn Khattab, Abdullah Ibn Umar, Abu Hurairah, Abu Musa Al Asy'ari, Abdullah ibn Abbas, 
Abdullah ibn Amr al Jarasyi, Said ibn Yazid, Amr ibn Ash, Zaid ibn Khalid al Juhani, Abdullah ibn Amir inb Rabi'ah, Abdullah ibn al Haris ibn Naufal, Shafiyah binti Syaibah.

2) Kalangan Keluarga: Saudarinya: Ummu Kalsum, saudara sesusunya: Auf ibn Harits, dua puteri saudarinya: Hafshah dan Asma, cucu saudaranya yang bernama Abd Rahman: Abdullah: Abdullah ibn Abu 'Atiq Muhammad ibn Abd rahman ibn Abu Bakr, dua putera saudarinya yang bernama Asma: Abdullah ibn Zubayr dan Urwah iban Zubayr. Dua orang cucu Asma: Ubbad dan Habib putera Abdullah ibn Zubayr, Ubbad ibn Hamzah ibn Abdullah ibn Zubayr dan puteri sudarinya Ummi Kalstum: Aisyah binti Thalhah.

3) Kalanagan hamba sahaya: Abu Amr, Zakwan, Abu Yunus dan Farukh.

4) Kalangan Tabi'in besar: Alqamah ibn Qais, Abdullah ibn Hakim, Abu Wail, Ibn Abi Malikah, Mu'azah al Adawiyah, Zirr ibn Hubays al Asady,Mutrif ibn al Sakhir, Hammam ibn al Harits, Abu Athiyah al Wa'd, Abu Ubaidah ibn Abdullah ibn Mas'ud, Abdullah ibn Syadad ibn al Had, Abdurrahman ibn Al Haris ibn Hisyam, Kedua putera Abd Rahman: Abu Bakar dan Muhamamd, Aiman al Makki, Samamah ibn Hazn al Qusyairi, al Haris ibn Abdillah ibn Abi Rabi'ah, Hamzah ibn Abdillah ibn Umar, Khabab, Salaim ibn Sailan, Sa'ad ibn Hisyam ibn Anir, Sulaiman ibn Yasar, Syuraih ibn Hani, Abu Shalih al Saman, Abis ibn Rabi'ah, Amir ibn Sa'ad ibn Abi Waqas, Thalhah ibn Abdillah ibn Usman, Thawus, Abu al Walid Abdullah ibn Haris al Basri, Abdullah ibn Syaqiq al Uqaili, Abdullah ibn Syihab al Khaulani, Abdurrahman ibn Syamash, Ubaidillah ibn Umair al laisi, 'Urak ibn Malik, Ubaidillah ibn Abdullah ibn Utbah, Alqamah ibn Waqas, Ali ibn al Husain ibn Ali, Imran ibn Hattan, Kuraib, Malik ibn Abi Amir al Ashbani, Farwan ibn Naufal al Asy'ja'l, Muhammadibn Qais ibn Makhramah, Muhamamd ibn al Muntasyir, Nafi' ibn Zubayr ibn Math'am, Yahya ibn Ya'mar, Abu Burdah ibn Abi Musa, Abu al Jauza al Rabi, Abu al Zubayr al Makki, Khairah umm Hasan, Shafiyyah binti Abu Ubaid, dan lannya.

Banyaknya hadis yang diriwayatkan dari Aisyah dan banyaknya orang yang meriwayatkan hadis darinya disebabkan karena:

1) Kedudukan Aisyah sebagai Ummul mu'minin yang paling dicintai oleh Rasulullah saw setelah Khadijah.(Muslim, Shahih Muslim, Fadail shahabah, no 4396)

2) Masa hidup Aisyah yang lama setelah wafat Rasulullah saw. membuat dia berkesempatan untuk bertemu banyak orang dan mengajarkan hadis.

3) Aisyah adalah perempuan pandai dan cerdas. Dia menjadi tempat bertanya bagi banyak orang, baik dikalangan sahabat maupun tabi'in. Para sahabat yang pernah bertanya kepada Aisyah diantaranya: 
a) Umar menyuruh bertanya kepada Aisyah tentang mandi janabat setelah jima yang tidak keluar air mani, setelah terjadi perbedaan pendapat tentang hal itu.

b) Muawiyah pernah mengirim surat kepada Aisyah menanyakan tentang hadis, setelah dia tidak mendapat jawaban yang memuaskan dari sahabat lain.

c) Ibnu Abbas mengakui bahwa Rasulullah saw adalah orang yang paling paham tentang salat witir Rasulullah saw.

d) Abd ibnAbbas, Abd Rahman ibn Azhar, dan al Musawwar ibn Makhramah, mereka mengutus Kuraib untuk bertanya kepada Aisyah tentang salat sunat 2 rakaat sesudah asar.

e) Abdullah ibn Umar, menanyakan kepada Aisyah tentang riwayat Abu Hurairah mengenai pahala dua qirath bagi orang yang menshalatkan dan mengantarkan janazah sampai kekubur.( Muslim:1574)

Kerena kecerdasan dan kuatnya hapalan yangdimiliki Aisyah, dia juga sering mengoreksi hadis-hadis yang diriwayatkan oleh para sahabat lainnya seperti terhadap hadis-hadis diantaranya yang diriwayatkan oleh: Umar ibn Khattab, Ali ibn Abi Thalib, Abdullah ibn Abbas, Abd ibn Umar, Abdullah ibn Amr ibn Ash, Abu Hurairah, Marwan Ibn al Hakam, Abu Sa'id al Khudri, Abd Ibn Mas'ud, Abu Musa Al Asy'ari dan lain-lain.

Mengenai koreksi Aisyah terhadap hadis-hadis yang diriwayatkan oleh para sahabat tersebut, Imam Badruddin Azzarkasyi, menulus sebuah buku khusus tentang koreksi Aisyah tesebut.

Hadis-hadis yang diriwaatkan Aisyah diantaranya adalah:

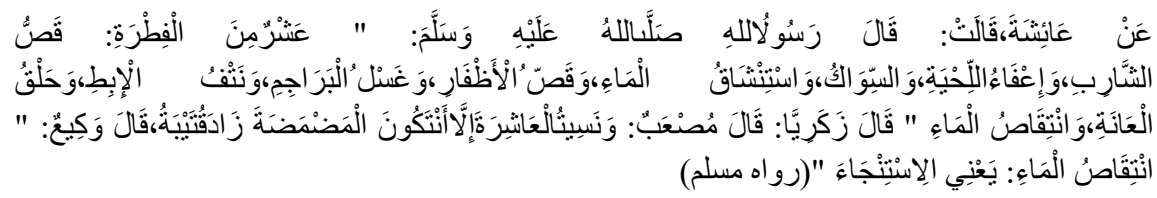

"Aisyah dia berkata, "Rasulullah shallallahu 'alaihi wasallam bersabda: "Ada sepuluh perkara dari fitrah; mencukur kumis, memanjangkan jenggot, bersiwak, beristinsyaq (memasukkan air ke dalam hidung), memotong kuku, bersuci dengan air, mencabut bulu ketiak, mencukur bulu kemaluan dan beristinja' dengan air." Zakariya berkata, Mush'ab berkata, "Dan aku lupa yang kesepuluh, kecuali ia adalah berkumur-kumur."Qutaibah menambahkan, " Waki' berkata, 'Bersuci dengan air maksudnya beristinja'." Dan telah menceritakannya kepada kami Abu Kuraib telah mengabarkan kepada kami Ibnu Abu Zaidah dari bapaknya dari Mush'ab bin Syaibah dengan sanad ini, seperti hadits tersebut, hanya saja dia menyebutkan, "Bapaknya berkata, 'Dan saya lupa yang kesepuluh."(HR Muslim, no.384) 


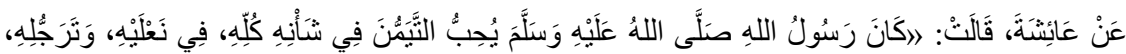

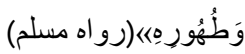

"Aisyah berkata: Adalah Rasulullah saw menyukai mendahulukan kanan dalam setiap keadaan, ketiak mengenakan sandal, ketika berjalan dan ketika bersuci". (HR Muslim no.268)

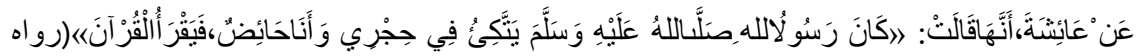

"Aisyah Berkata: Adalah Rasulullah saw bersandar di asuhanku, dan aku dalam keadaan haid, lalu beliau menbaca AI Qur'an." (HR Muslimno. 301)

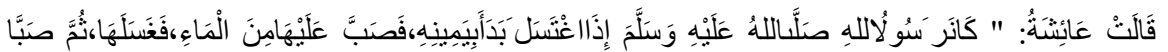

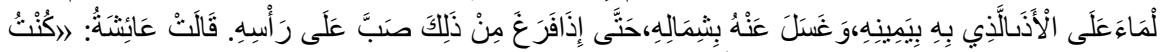

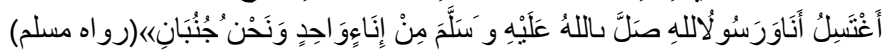

"Aisyah berkata: Adalah Rasulullah saw. apabila mandi beliau memulai dengan kanannya dengan menuangkan air padanya dan membasuhnya dngan kirinya, sesudah selesai tangan lalu beliau menuangkan air ke kepalanya. Aisyah berkata: Aku dan Rasulullah saw mandi (dengan air) dari satu bejana dan kami berdua junub" (HR Muslim no. 321)

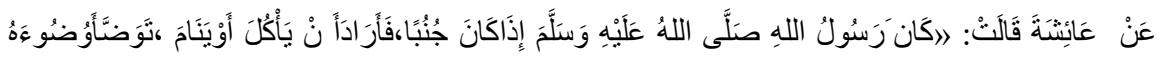

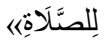

"Aisyah berkata: Adalah Rasulullah saw apabila beliau dalam keadaan janabah, dan beliau ingin makan atau tidur, beliau berwudhu seperti wudhu untuk shalat". (HR Muslim no. 305)

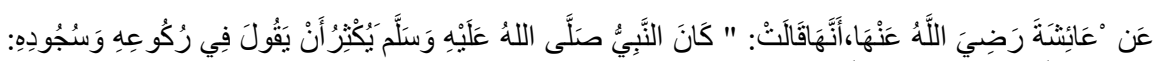

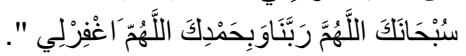

"Aisyah berkata: Adalah Rasulullah saw banyak mengucap pada ruku' dan sujudnya:" Maha suci engkau Ya Allah Tuhan kami dan dengan memujiMu, ampunilah aku" (HR Bukhari no 775)

\section{Ummu Salamah}

Namanya adalah Hindun binti Abi Umayyah ibn al Mughirah ibn Abdillah ibn Umar ibn Makhzum al Makhzumiyah. Dia ikut berhijrah dua kali yaitu ke Habsyah dank e Madinah. Dia dinikahi oleh Rasulullah saw.pada tahun keempat hijriyah. Sebelum hijrah ke Habyah dia sudah menikah dengan Abi Salamah ibn Abd al Asad dan memperoleh dua orang anak yaitu: Umar dan Zainab. Ketika terjadi perang uhud, suaminya (Abu Salamah) terluka dan kemudian wafat (th.3 H). Kemudian Ummu Salamah dinikahi oleh Rasulullah saw. 
Ummu Salamah banyak meriwayatkan hadis dari Rasulullah saw. yaitu sebanyak 622 Hadis. Diantara hadis tersebut, ada hadis yang diriwayatkannya langsung dari Rasulllah saw, dan ada pula yang diriwayatkan dari orang lain, seperti dari Abu Salamah dan dari Fathimah binti Rasulullah saw.

Orang-orang yang meriwayatkan hadis dari beliau diantaranya adalah: Umar dan zainab, keduanya anak beliau sendiri, Aisyah, Ibn Abbas, Abi Said al Khudri, Amir Ibn Umayyah, Mus'ab Ibn Abdillah ibn Abi Umayyah, Abdullah ibn Rafi, Nafi, Safinah, Abu Katsir, Ibn Safinah, Khairah Ummu Hasan al Bashri, Sulaiman ibn Yasar, Usamah ibn Zaid ibn Haritsah, Hind binti al Harits, Shafiyah binti Syaibah, Abu Usman al Nahdy, Humaid dan Abu Salamah ibn Abd Rahman ibn Auf, Said ibn al Musayyab, Abu Wail, Shafiyyah binti Muhshan, al Sya'by, Abd Rahman ibn Abi Bakr, Usman ibn Abdillah ibn Mauhib, Urwah ibn Zubair, Kuraib maula Ibn Abbas, Qubaisyah ibn Zuwaib, Nafi maula ibn Umar dan Ya'la ibn Mamlak.(Ibn Hajar al Asqalani, al ishabah, h.423)

Diantara hadis yang diriwayatkan adalah:

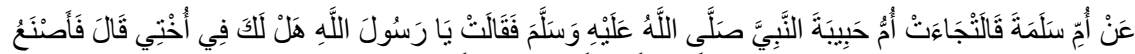

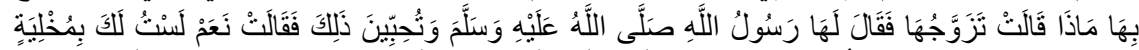

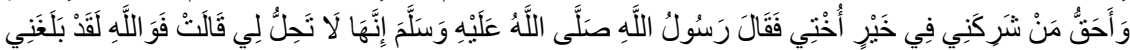

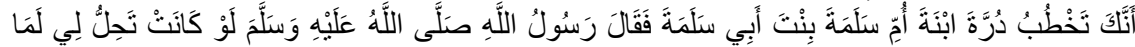

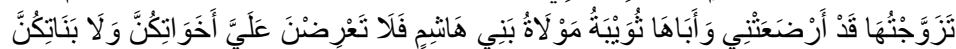
"Ummu Salamah berkata: Ummu Habibah pernah menemui Nabi shallaallahu 'alaihi wa sallam, lalu ia bertanya: "Wahai Rasulullah! Maukah dengan saudariku?" Beliau bersabda: "Apa yang aku lakukan terhadapnya?" ia menjawab; "Engkau nikahi ia." Ialu Rasulullah shallaallahu 'alaihi wa sallam bersabda: "Apakah engkau menginginkan hal itu?" ia menjawab: "Ya, aku tidak bermaksud mencelakakanmu dan aku hanya ingin membahagiakan saudaraku." kemudian Rasulullah shallaallahu 'alaihi wa sallam bersabda: "Sesungguhnya ia tidak halal bagiku, " ia menjawab; "Demi Allah, telah sampai kabar kepadaku bahwa engkau melamar Durrah binti Ummu Salamah binti Abi Salamah, lalu Rasulullah shallaallahu 'alaihi wa sallam menuturkan: "Jika ia memang halal untukku niscaya aku akan menikahinya, ia menyusuiku dan ayahnya Tsuwaibah adalah budak Bani Hasyim, maka janganlah kalian menawarkan saudari dan anak perempuan kalian untukku", ( HRAhmad no : 25288)

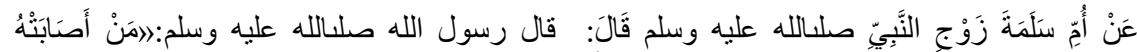

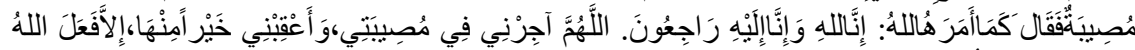

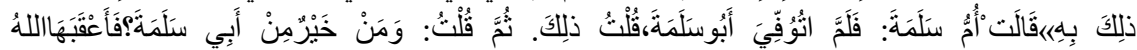

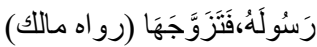


"Ummu salamah, isteri Nabi saw berkata: Bahwa Rasulullah saw bersabda: Siapa yang ditimpa musibah kemudian dian berkata seperti yang disuruh Allah "sesungguhnya kami adalah milik Allah dan sesungguhnya kami akan kembali kepada Nya, ya Allah berilah aku ganjaran atas musibah yang menimpa aku dan gantikanlah yang lebih baik daripada nya" melainkan Allah akan melakukan yang demikian itu.

Ummu salamah berkata: ketika diwafatkan Abu salamah, Aku mengatakan seperti doa yang diajarkan Rasulullah saw, aku berkata: Siapa yanglebih baik dari Abu Salamah, Maka Allah menggantikannya dengan Rasulullah saw". (HR Malik no: 498)

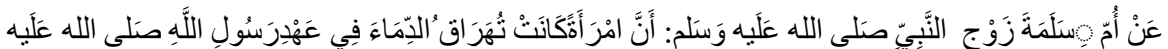

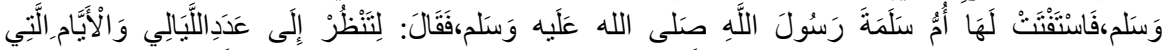

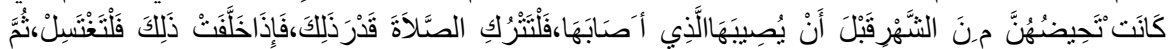

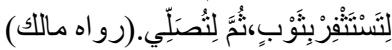

"Ummu Salamah, isteri Nabi SAW berkata: Seorang perempuan mengeluarkan darah (yang terjadi pada masa Rasulullah saw) Maka Ummu salamah meminta fatwa kepada Rasulullah saw tentang hal itu. Rasulullah saw bersabda: hendaklah dia menunggu beberapa hari dan malam seperti haid pada bulan sebelumnya, hendaklah dia tinggalkan sholat pada hari-hari itu, apabila sudah berlalu (hari hari) yang demikian itu, maka hendaklah dia mandi, menutup dengan kain kemudian dia shalat". (HR Malik: 199)

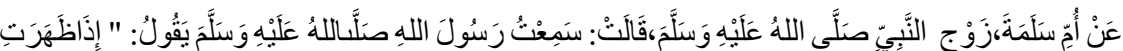

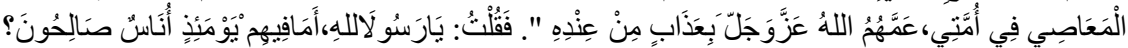

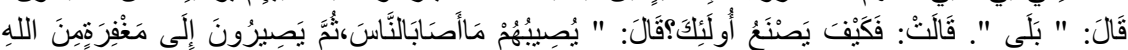

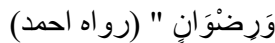

"Ummu Salamah, isteri Nabi saw berkata: Rasulullah saw bersabda: Apabila bermunculan maksiyat pada ummatku, Allah menurunkan azabnya secara umum. Maka aku bertanya: Hai Rasulullah! Adakah pada waktu itu orang yang shaleh? Rasulullah menjawab: Ya. Aku bertanya: Maka bagaimana yang demikian itu terjadi? Rasulullah menjawab: Menimpa kepada mereka (Orang shaleh) apa yang terjadi pada orang lainnya, kemudian mereka mendapatkan ampunan dan ridha Allah" (HR Ahmad: 25382)

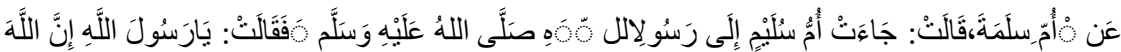

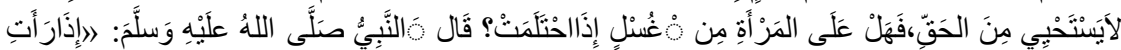

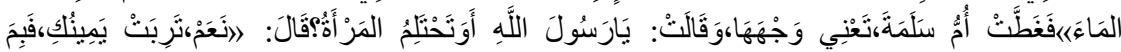

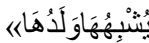

"Ummu Salamah berkata: Ummu Sulaim datang kepada Rasulullah saw dan berkata: Ya Rasululallah, Seseungguhnya Allah tidak malu dalam 
(mengungkapkan) kebenaran apakah perempuan wajib mandi jika bermimpi? Nabi menjawab: Jika dia melihat air. Maka Ummu salamah menutup wajahnya, dan dia bertanya: Apakah perempuan juga bermimpi? Nabi menjawab; Ya, maka bagaimana ada keserupaan nya dengan anaknya". (HR Ahmad: 26503)

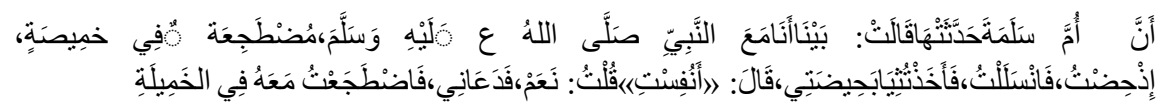

"Ummu Salamah berkata: Ketika aku berbaring bersama Rasulullah saw dalam selimut, tiba-tiba aku haid, maka pergi pelan-pelan, aku mengambil pakaian haid. Rasulullah saw bertanya: Apakah kamu haid? Aku menjawab: Ya, Rasulullah saw memanggilku dan aku berbaring bersama beliau dalam satu selimut". (HR Bukhari: 298)

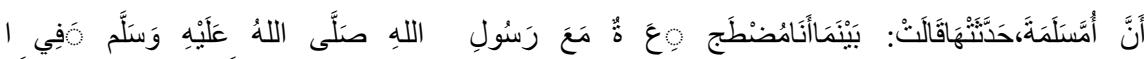

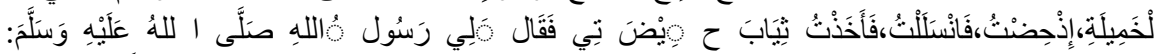

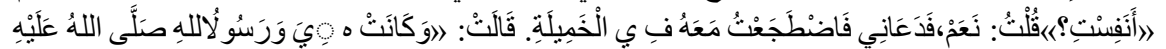

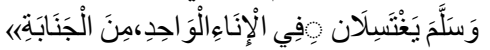

"Ummu Salamah berkata: Ketika aku berbaring bersama Rasulullah saw dalam selimut, tiba-tiba aku haid, maka pergi pelan-pelan, aku mengambil pakaian haid. Rasulullah saw bertanya: Apakah kamu haid? Aku menjawab: Ya, Rasulullah saw memanggilku dan aku berbaring bersama beliau dalam satu selimut. Ummu Salamah juga berkata bahwa dia dan Rasulullah saw mandi bersama Rasulullah saw mandi janabah dalam satu bejana". (HR. Muslim no. 444

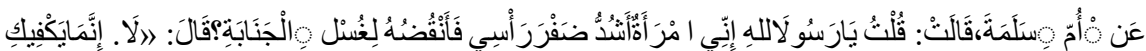

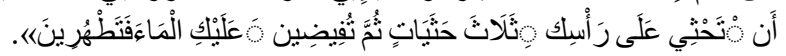

"Umi Salamah berkata: Ya Rasulallah, sesungguhnya aku perampuan yang mempunyai rambut sangat berpintal, apakah aku (harus) mengurainya untuk mandi janabah? Rasulullah saw menjawab: Tidak, cukup bagimu menumpahkan air pada kepalamu tiga kali kemudian meratakan air (kebadanmu) maka sucilah." (HR Muslim no. 497)

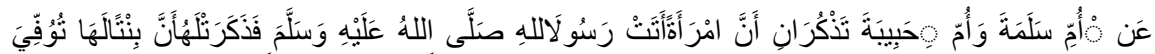

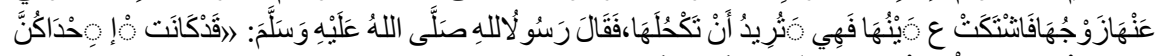

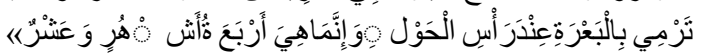

"Ummu Salamah dan Ummu Habibah menyebutkan bahwa ada seorang perempuan datang kepada Rasulullah saw dan menyebutkan banwa dia mempunyai anak permpuan yang ditinggal mati oleh suaminya, lalu sakit matanya dan dia ingin memakaikan celak mata padanya. Maka Rasulullah saw bersabda: Sesungguhnya dulu kalian membuang kotoran (iddah) satu tahun, dan (sekarang) hanya empat bulan sepuluh hari". (HR Muslim no 2735) 
3) Maimunah binti al Haris

Maimunah binti al Harits adalah isteri Rasulullah saw yang dinikahi beliau pada bulan Zul qa'dah tahun 7 hijrah. Sabelumnya Maimunah pernah menikah dengan Abu Rahm ibn Abd-al Uzza sebelum dia masuk Islam, la wafat tahun $51 \mathrm{H}$. Maimunah banyak meriwayatkan hadis dari Rasulullah saw. Orang -orang yang meriwayatkan hadis langsung dari beliau adalah: Abdullah ibn Abbas, Abdullah ibn Syidad ibn al Hadi, Abd Rahman ibn al Saib al Hilali, Yazid ibn al Ashom, bekas budaknya: Nudbah, Atha ibn Yasar, Sulaiman ibn Yasar, Ibrahim ibn Abdillah ibn Ma'bad, Kuraib maula Ibn Abbas, Ubaidillah ibnal Sibaq, Ubaidillah ibn Utbah, Al Aliyah binti al Sabi, dan yang lainnya. (Tahzib al tahzib, juz XII h.453)

Diantara hadis yng diriwayatkan beliau adalah:

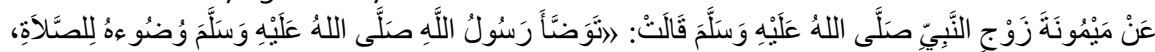

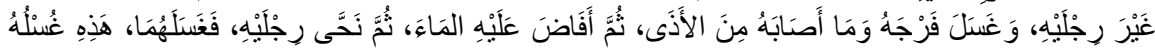

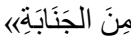

"Maimunah isteri Rasulullah saw berkata: Rasulullah saw berwudlu seperti wudlu untuk salat kecuali membasuh dua kaki dan membasuh kemaluan dari kotoran, kemudian meratakan air pada badannya, lalu memindahkan kakinya dan membasuh keduanya. Inilah (cara) mandinya dari janabah". (HR Bukhari no. 249)

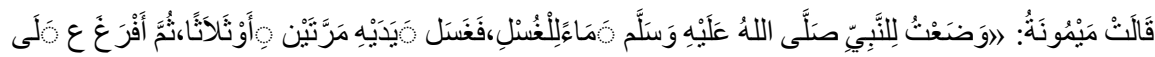

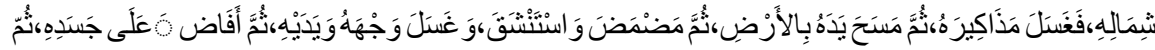

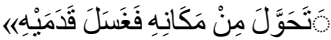

"Maimunah isteri Rasulullah saw berkata: Aku meletakkan air untuk mandi Rasulullah saw, maka beliau membasuh dua tangannya dua atau tiga kali, kemudian beliau dengan tangan kirinya membasuh kemaluannya, lalu menyapukannya ke tanah, laku berkumur-kumur dan memasukkan air ke hidung, membasuh muka dan dua tangannya, kemudian meratakan ait ketubuhnya, kemudian berpundah tempat lalu membasuh dua kakinya". (HR Bukhari no. 257)

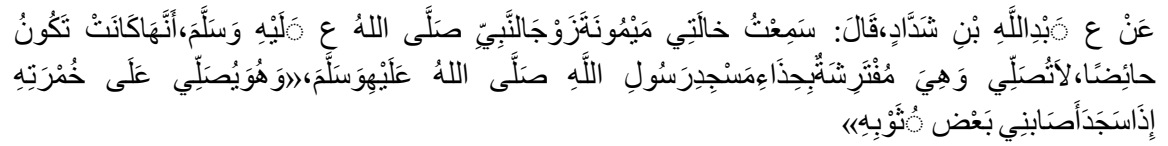

"Abdullah bin Syidad berkata: Aku mendengar bibiku Maimunah isteri Rasulullah saw berkata: bahwa dia sedang haid dan dia berbaring di kain Rasulullah saw yang digunakan untuk solat, dan Rasulullah saw solat pada tikarnya (yang kecil), jika dia sujud maka sebagian pakaiannya mengenai aku". (HR Bukhari no.321)

4) Hafshah binti Umar bin Al Khattab.

Ibunya adalah Zainab binti Maz'un, saudara perempuan Usmaan ibn Maz'un. Hafsah dilahirkan ketika kaum Quraisy sedang membangun Baitullah, lima tahun sebelum Rasul saw diutus. Hafshah sebelumnya telah menikah dengan Khunays 
ibn Hudhafah al-Sahmi, sahabat Rasulullah yang ikut hijrah ke Habsyah dan Madinah serta ikutserta dalam perang Badar dan perang Uhud, dan dia wafat di Madinah.Dan Hafsah saat itu berusia 18 tahun. Melihat puterinya menjadi janda pada usia sangat muda, Umar pernah menawarkan Hafsah kepada Usman ibn Affan yang baru ditinggal mati oleh isterinya yang bernama Ruqayyah (puteri Rasulullahsaw) dan juga kepada Abu Bakar, tetapi keduanya: Usman dan Abu Bakar tidak mau. Dan kemudian Hafsah dinikahi oleh Rasulullah saw. Dan Usman dinikahkan oleh Rasulullah saw. Dengan puteri beliau yang bernama Ummi Kalstum. Rasulullah menikahi Hafsah pada bulan Sya'bantahun ketiga Hijrah, dan dia wafat pada tahun ditaklukkannya Afrika yaitu tahun $45 \mathrm{H}$.

Hafsah meriwayatkan hadis-hadis dari Nabi saw. secara langsung, dan ada juga yang dari orang lain. Sahabat yang neriwayatkan hadis dari Hafshah adalah: Abdullah ibn Umar, Hamzah ibn Abdillah ibn Umar dan isterinya Shafiyah binti Abi Ubaid. Tabiin yang meriwatkan hadis darinya adalah: Haritsah ibn Wahab, Al Mutahalib ibn Abi Wadhaah, Ummu Mubasyir al Anshariyah, Abd rahman ibn Harits dan lain-lain ( Tahzib al Tahzib juz XII h. 410-411)

Hadis-hadis yang diriwayatkan Hafsah diantaranya adalah:

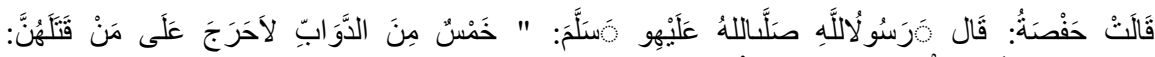

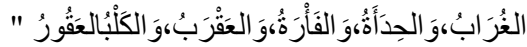

"Hafshah berkata: Rasulullah saw bersabda: Ada lima dari binatang yang tidak berdosa orang yang membunuhnya, yaitu: Burung gagak, burung rajawali, tikus, kalajengking dan anjing yang suka mnggigit. (HR Bukhari no. 1828)

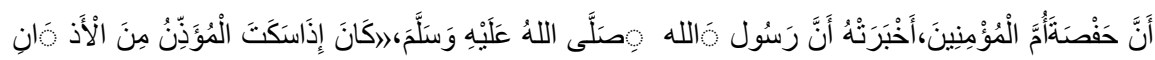

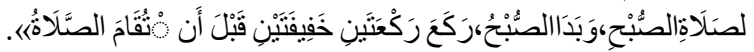

"Hafshah Ummul Mu'minin berkata: Bahwa Rasulullah saw, ababila muazzin selesai azan untuk salat subuh, beliau memulai dengan salat dua rakaat yang pendek sebelun dikerjakan salat (subuh)." (HR Muslim no. 87)

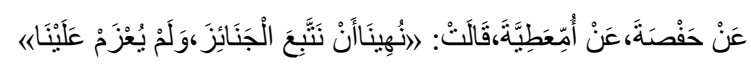

"Hafshah berkata: Dari Umi Atiyah berkata: Kami dillarang untuk mengantarkan Janazah, tetapi larangan itu tidak terlalu keras". (HR Abu Daud: 2754)

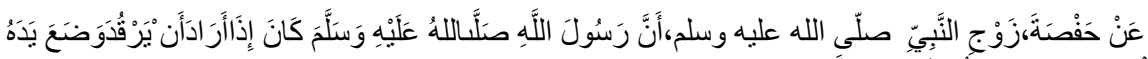

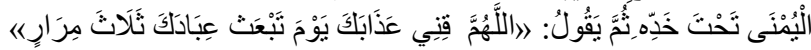

Hafshah Isteri Nabi Saw berkata: Bahwa Rasulullah saw jika ingin tidur, beliau meletakkan tangannya yang kanan pada pipinya dan berkata: Ya Allah peliharalah aku dari azabmu pada hari ketika Engkau membangkitkan hamba-hambamu 3 kali. (HR Abu Daud no. 5045) 
5) Ummu Habibah.

Namanya adalah Ramlah bintiAbi Sufyan ibn Harb ibn Umayyah. Ibunya adalah Safiyah binti Abi Al Ash, bibi dari Usman ibn Affan.Dia menikah dengan Ubaidillah ibn Jahsy dari Khuzaima.Dia memiliki seorang anak yang bernama Habibah, sehingga dia dijuluki Ummu Habibah. Dia hijrah bersama suaminya Ubaidillah ke Habsyah pada hijrah kedua, dan suaminya murtad kemudian meninggal di Habsyah, dan Ummu Habibah tetap teguh dengan keislamannya. Kemudian Nabi saw mengutus Ja'far ibn Abi Thalib untuk melamar Ummu Habibah. Nabi menikahi Ummu Habibah pada tahun 6 atau7 $\mathrm{H}$ dan saat itu Ummu Habibah masih di Habsyah dan berumur 40 tahun, dan dia wafat pada $42 \mathrm{H}$.

Ummu Habibah banyak meriwayatkah hadis dari Rasulullah saw. Hal tersebut disebabkan oleh karena dia termasuk perempuan yang terdahulu masuk Islam, dia hidup lama setelah Rasulullah saw wafat dan dia termasuk perempuan bangsawan arab dan aktif. Kebanyakan dari hadis-hadis itu diriwayatkannya secara langsung dari Rasulullah saw, dan sebagian lagi dari Zainab binti Jahsy. Orang-orang yang meriwayatkan dari Ummu Habibah diantaranya adalah: anaknya : Habibah, saudaranya: Muawiyah, anak laki-laki saudaranya: Abdullah ibn Utbah ibn Abi Sufyan, anak saudarinya perempuan: Abu Sufyan ibn Said ibn Mughirah, budaknya: Salim ibn Siwar dan Abu al Jarrah, Abu al Shalih al Samman, Urwah ibn al Zubair, Zainab binti Ummi Salamah, Shafiyah binti Syaibah dan Syahr ibn Huisyab.

Diantara hadis-hadis yang diriwayatkan nya adalah:

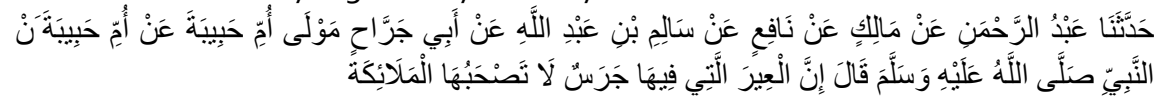

"Ummu Habibah berkata: dari Nabi shallallahu 'alaihi wasallam, beliau bersabda: "Sesungguhnya Malaikat tidak akan menyertai kafilah yang terdapat padanya lonceng."(Musnad Ahmad 26770)

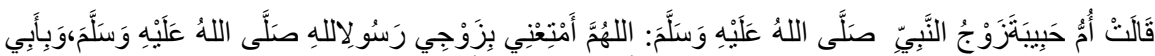

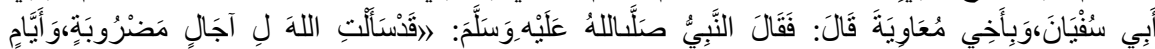

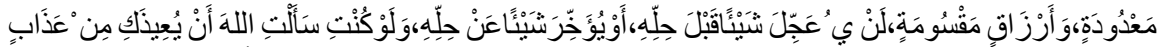

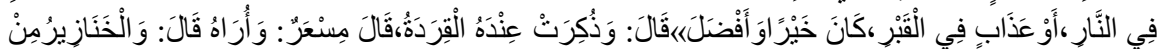

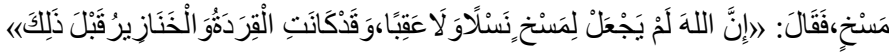

Ummu Habibah pernah berdoa sebagai berikut; 'Ya Allah, berikanlah aku kenikmatan (panjangkanlah usiaku) bersama suamiku, Rasulullah shallallahu 'alaihi wasallam, ayahku, Abu Sufyan, dan saudaraku, Muawiyah.' Mendengar doa itu, Rasulullah shallallahu 'alaihi wasallam berkata kepada istrinya, Ummu Habibah: 'Sesungguhnya kamu memohon kepada Allah Subhanahu wa Ta'ala: ajal, kematian, dan rezeki yang telah ditentukan, yang Allah tidak akan 
memaajukan ataupun memundurkan sebelum waktunya. Apabila kamu memohon kepada Allah Suhhanahu wa Ta'ala agar Dia menyelamatkanmu dari siksa neraka dan siksa kubur, maka hal itu lebih baik bagimu.' Abdullah bin Mas'ud berkata; 'Ada seorang laki-laki bertanya; 'Ya Rasulullah, apakah kera dan babi itu berasal dari manusia yang telah berubah rupa? 'Rasulullah shallallahu 'alaihi wasallam menjawab: 'Sesungguhnya Allah Azza wa Jalla tidak akan menghancurkan atau menyiksa suatu kaum, kemudian menjadikan keturunan bagi mereka. Sesungguhnya keturunan babi dan kera itu sudah ada sebelumnya.'(Shahih Muslim 4815)

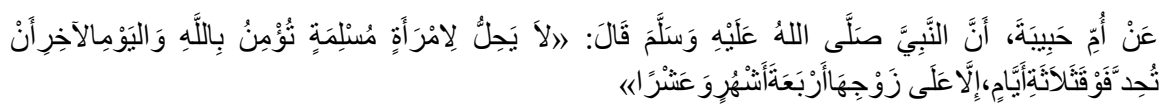

"Ummu Habibah berkata: Bahwa Nabi saw bersabda: Tidak halal bagi seorang muslimah yang beriman kepada Allah dan hari akhir untuk berkabung lebih dari tiga hari, kecuali terhadap kematian suami selama empat bulan sepuluh hari. (HR Bukharino.5339)

6) Zainab binti Jahsy.

Zainabbinti Jahsy ibn Rababibn Ya'mar, nama sebelumnya adalah Barra binti Jahsy. Ketika dia menjadi isteri Rasulullah saw namanya dirubah menjadi Zainab. Sebelum menikah dengan Rasulullah saw, dia sudah menikah dengan Zaid ibn Haritsah, bekas budak Rasulullah saw yang kemudian menjadi anak angkat beliau setelah dia dimerdkakan oleh Rasulullah saw. Setelah Zainab bercerai dari Zaid, dia dinikahkan langsung oleh Allah SWT melalui firmannya pada surah al Ahzab (33) ayat 27. Pernikahan Zainab dengan Rasulullah saw terjadi pada tahun ke $3 \mathrm{H}$. dan dia meninggal pada tahun $20 \mathrm{H}$.

Hadis yang diriwayatkan Zainab tidak terlalu banyak, seperti para sahabat dan isteri nabi yang lain pada umumnya, karena Zainab adalah isteri Rasulullah yang terdahulu wafat sesudah wafatnya Nabi saw. Hadis hadis itu di riwayatkan langsung dari Nabi saw. Orang-orang yang meriwayatkan hadis dari beliau adalah: anak saudaranya: Muhammad ibn Abdillah ibn Jahsy, bekas budaknya: Madzkur dan Kalsum ibn al Musthafa, anak tiri Nabi: Zainab binti Abi salamah, dan ummu Habibah binti Abi Sufyan.

Hadis yang diriwayatkan diantaranya adalah:

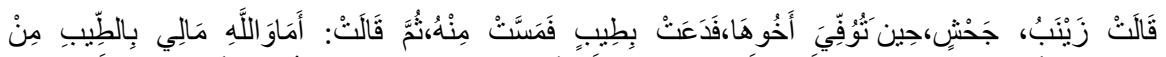

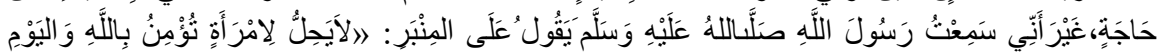

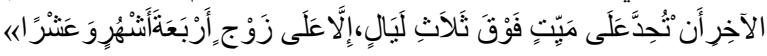

Zainab binti Jahsy, ketika wafat saudaranya berkata bahwa ia mendengar Rasulullah saw bersabda: Tidak boleh atas perempuan muslimah yang beriman 
kepada Allah dan hari akhir untuk berkabung lebih dari 3 malam kecuali atas kematian suaminya selama empat bulan sepuluh hari (HR Bukhari no. 5335)

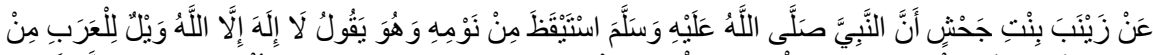

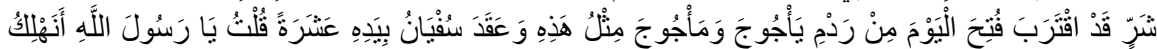

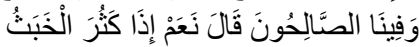

Zainab binti Jahsy berkata: Nabi Shallallahu 'alaihi wa Salam bangun tidur dan beliau mengucapkan: "LAA ILAAHA ILLALLAAH, celakalah bangsa arab dari keburukan yang mendekat, saat ini penghalang Ya'juj dan Ma'juj telah terbuka seperti ini -Sufyan dan lainnya melekatkan kesepuluh jarinya- aku (Zainab) bertanya: Wahai Rasulullah, apakah kita akan dibinasakan sementara ditengahtengah kami ada orang-orang shalih? Beliau menjawab: "Ya, bila kekejian banyak (menyebar)."(Shahih Muslim, no: 5128)

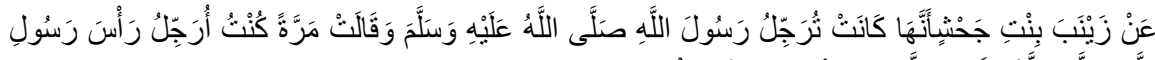

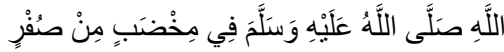

"Zainab binti Jahsy berkata: bahwa dia pernah menyisir rambut Rasulullah shallallahu 'alaihi wasallam, ia pernah berkata, "Aku pernah menyisir rambut Rasulullah shallallahu 'alaihi wasallam di dalam bejana yang terbuat dari kuningan."(Musnad Ahmad: 25527)

\section{7). Shafiyyah binti Huyay}

Shafiyyah binti Huyay ibn Akhtab ibn Sa'id ib Tsa'labah al Israiliyah adalah perempuan cerdas, bangsawan Yahudi Khaibar yang mempunyai kedudukan dan terpandang. Sebelumnya dia telah menikah dengan Salam ibn Abd al Haqiq, kemudian dengan Kinanah ibn al Haqiq.Keduanya adalah penyair Yahudi.Pada waktu perang Khaibar, Kinanah mati terbunuh dan Shafiyah menjadi tawananperang. Setelah selesai perang khaibar, Shafiyyah dinikahi Rasulullah saw dengan mahar dia beri kemerdekaannya. Shafiyyah wafat pada tahun $50 \mathrm{H}$.

Shafiyyah meriwayatkan hadis-hadisnya langsung dari Nabi saw. Tetapi tidak banyak. Hal tersebut karena dia masuk Islam pada terkebelakang dari yang lain, disampingkarena dia berasal dari suku yang tidak erat kaitannya dengan Nabi. Orang -orang yang meriwayatkan hadis dari dia adalah: Kinanah dan Yazid ibn Ma'tab, Ali ibn al Husain ibn Ali, Muslim ibn Shafwan dan Ishaq ibn Abdillah ibn al Haris. 
Hadits-hadits yang diriwayatkannya diantaranya:

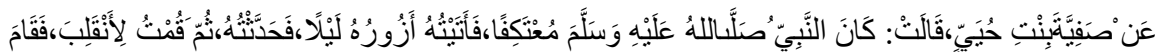

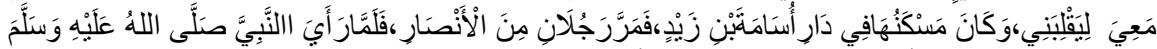

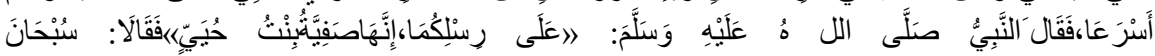

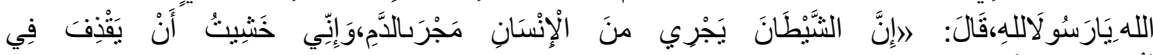

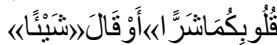

Shafiyah ia berkata, "Rasulullah shallallahu 'alaihi wasallam sedang beri'tikaf (berdiam diri di masjid), maka pada waktu malam aku mengunjungi beliau dan bercakap-cakap. Aku lalu berdiri untuk pulang, dan beliau juga ikut berdiri bersamaku untuk mengantarku -waktu itu Shafiyah tinggal di rumah Usamah bin Zaid-. Lalu ada dua orang laki-laki Anshar melintas, ketika mereka melihat Nabi shallallahu 'alaihi wasallam, mereka bergegas. Maka Nabi shallallahu 'alaihi wasallam pun bersabda: "Hendaklah kalian pelan-pelan, dia itu adalah Shafiyah binti Huyay." Keduanya langsung berkata, "Maha Suci Allah, ya Rasulullah." Beliau bersabda: "Sesungguhnya setan mengalir dalam diri manusia seperti mengalirnya aliran darah. Maka aku takut dia akan memasukkan sesuatu ke dalam hati kalian."Atau beliau mengatakan, "(memasukkan) Keburukkan (HR Bukhari no. 3039)".

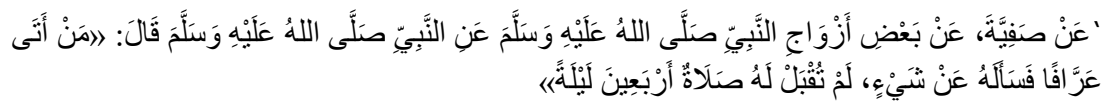

"Siapa mendatangi peramal, kemudian dia bertanya kepadanya tentang sesuatu maka tidaklah diterima shalatnya sepanjang empat puluh hari [Muslim no. 5782]

8) Juwayriyah binti al Harits.

Dia adalah Juwairiyah binti al Haris ibn Abi Dhirar ibn al Habib al Khuza'iyah. Dia adalah perempuan bangsawan yang ditawan ketika kaum muslimin menalukkah bani Musthalik padaperang Muraisi pada tahun 5 atau 6 kenabian. Rasulullah saw membebaskannya kemudian menikahinya, dan pada saat itu dia berumur 20 tahun.Sebab pernikahanitu, Rasul membebaskan 100 orang keluarga dari bani Musthalik. Sebelum itu Juwairiyah pernah menikah dengan Musafi' ibn Shafwan yang meninggal terbunuh pada perang Muraisi tersebut. Dia wafat tahun $56 \mathrm{H}$.

Juwairiyah tidak banyak meriwayatkan hadis dari Rasulullah saw. Semua hadis itu diriwayatkan langsung dari Nabi saw. Sedikitnya hadis yang diriwayatkannya disebabkan karena dia masuk Islam agak akhir, yaitu sesudah sukunya dikalahkan oleh pasukan Rasulullah saw. Orang-orang yang meriwayatkan hadis darinya adalah: Abdullah ibn Abbas, Ubaid ibn al Sibaq, Abu Ayyub al Maraghi, Mujahid ibn Jabbar, Kuraib, Kulsum ibn al Musthaliq dan Abdullah ibn Syidad abn al-Hadi 
Diantara hadis yang diriwayatkannya adalah:

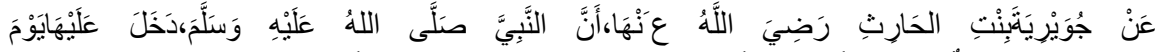

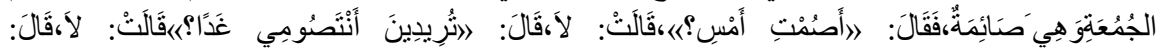

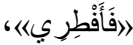

Juwairiyah binti Al Harits dia berkata, "Sesungguhnya Nabi shallallahu 'alaihi wasallam pada hari Jum'at datang menemuinya, yang ketika itu dia sedang berpuasa. Beliau kemudian bertanya kepadanya: "Apakah kamu kemarin berpuasa?" dia menjawab, "Tidak." Beliau bertanya lagi: "Apakah kamu besok mau berpuasa?" dia menjawab, "Tidak." Maka beliau pun bersabda: "Berbukalah kamu. (Musnad Ahmad no: 26154)".

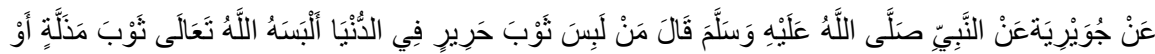
تَؤَبَا مِنْ نَارِ Juwairiyah menceriterakan dari Nabi shallallahu 'alaihi wasallam, beliau bersabda: "Barangsiapa mengenakan pakaian dari sutera di dunia, maka Allah Ta'ala akan memakaikan kepadanya pakaian kehinaan, atau pakaian dari api Neraka (Musnad Ahmad no: 26155)

9) Saudah binti Zam'ah.

Saudah binti Zamaah ibn Qais ibn Abd Syams sebelumnya telah menikah dengan Sakran ibn Amr ibn Abd Syams. Dia dan suaminya masuk Islam dan ikut hijrah ke Abbesinia yang kedua.Setelah suaminya meninggal di Habsyah, Saudah dinikahi oleh Rasulullah saw. Pada bulan Ramadan tahun ke 10 kenabian.Dialah perempuan pertama yang dinikahi Rasulullah saw setelah wafat Khadijah. Setelah Rasulullah saw menikah dengan Aisyah, Saudah memberikan gilirannya bersama Rasulullah saw kepada Aisyah. Dia wafat pada akhir masa pemerintahan khalifah Umar ibn al-Khattab.

Hadis-hadis yang diriwayatkan Saudah tidak banyak, karena kehidupannya bersama nabi tidak begitu rapat, sebab dia menyerahkan gilirannya bersama Nabi saw kepada Aisyah. Orang-orang yang meriwayatkan hadis dari Saudah adalah: Ibn Abbas dan Yahya ibn Abdillah ibn Abd Rahman.

Diantara hadis yang diriwayatkan adalah:

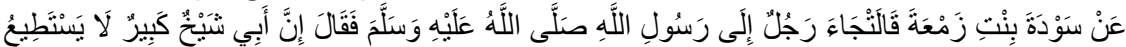

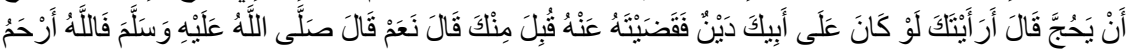
حُجَّ عَنْ أَبِيكَ

Saudah Binti Zam'ah berkata, "Seseorang datang kepada Rasulullah shallallahu 'alaihi wasallam kemudian dia berkata, "Sesungguhnya bapakku adalah seorang yang sudah tua dan tidak mampu lagi untuk melaksanakan haji." Beliau menjawab: "Apa pedapatmu sekiranya bapakmu mempunyai hutang, apakah kamu akan melunasinya?" dia menjawab, "Ya." Kemudian beliau shallallahu 
'alaihi wasallam bersabda: "Allah lebih penyayang, maka lakukanlah haji untuk bapakmu."(Musnad Ahmad no: 26149)

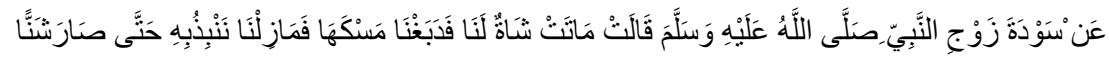
Saudah isteri Nabi shallallahu 'alaihi wasallam, berkata, "Seekor kambing milik kami mati kemudian kulitnya kami samak, dan kami terus saja mengerjakannya hingga menjadi geribah (wadah air dari kulit).( Musnad Ahmad no: 26150)

\section{b) Sahabiyah yang bukan isteri Nabi saw.}

Selain dari isteri Rasulullah saw. Sahabat perempuan yang banyak meriwayatkan hadis adalah:

\section{1) Asma binti Abi Bakr}

Asma binti Abi Bakr adalah isteri Zubair ibn Awwam, dia saudara Aisyah yang lebih tua dari Aisyah belasan tahun. Dia masuk Islam ketik a masih di Mekah, dan ia orang ke 18 yang masuk Islam, dan dialah yang mengantarkan makanan dan minuman ketika Rasulullah saw bersama Abu Bakar bersembunyi di gua tsur ketika menjelang berhijrah ke Madinah. Dia dinikahi oleh Zubair ketika masih di Mekkah dan berhirah ketika dia sedang mengandung anaknya yang bernama Abdullah inb Zubair.

Asma meriwayatkan hadis secara langsung dari Rasulullah saw. Orang-orang yang meriwayatkannhadis darinya adalah: Abdullah dan Urwah ibn Zubair, keduanya adalah putera beliau, Cucuya: Ubbad ibn bdullah ibn Zubair, Abdullah ibn Urwah ibn Zubair dan Fathimah binti Munzir ibn Zubair, cicitnya: Ubbad ibn Hamzah, ibn Abdullah ibnZubair, bekas budaknya Abdullah ibn Kaisan, Shofiyyah binti Syaibah, Abdullah ibn Abbas, Muslim al Ma'ry, Abu Naufal ibn Abi Aqrab, Abdullah ibn Abi Mulaikah Wahab ibn Kaisan dan lainnya.

Asma adalah sahabiyah yang bukan isteri Rasulullah yang paling banyak meriwayatkan hadis, hal itu disebabkan karena:

a. Dia dibesarkan dan di didik di lingkungan keluarga sahabat utama Rasulullah, yang kemudian menikah dengan sahabat Rasulullah, disamping itu dia adalah perempuan cerdas dan sangat bersemangat dengan agamanya.

b. Dia dianugerahi umur yang panjang yaitu selama 63 tahun setelah wafat Rasulullah saw. Sehingga banyak kesempatan untuk mengajarkan ilmnya. Dia wafat pada tahun $73 \mathrm{H}$ dalam usia 100 tahun.

Diantara hadis yang diriwayatkannya adalah:

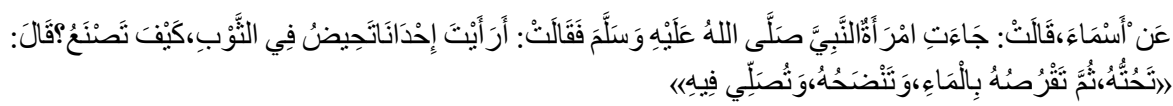

Asma' binti Abu Bakar Ash Shiddiq berkata, "Seorang wanita bertanya kepada Rasulullah shallallahu 'alaihi wasallam, katanya, "Wahai Rasulullah, bagaimana pendapatmu bila seorang dari kami bajunya terkena darah haid.Apa yang harus 
dilakukannya?" Rasulullah shallallahu 'alaihi wasallam lalu menjawab: "Jika darah haid mengenai pakaian seorang dari kalian, maka hendaklah ia bersihkan darah yang mengenainya, lalu hendaklah ia percikkan air padanya, kemudian hendaklah ia shalat dengannya."(Shahih Bukhari, no: 296)

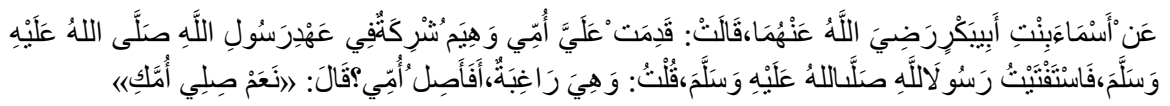

Asma' binti Abu Bakr radliallahu 'anhuma berkata; Ibuku menemuiku saat itu dia masih musyrik ketika quraisy muslimin mengikat perjanjian dengan Rasulullah shallallahu 'alaihi wasallam dan ayahnya, lalu aku meminta pendapat kepada Rasulullah shallallahu 'alaihi wasallam. Aku katakan; "Wahai Rasulullah, Ibuku datang kepadaku dan dia sangat ingin (aku berbuat baik padanya), apakah aku harus tetap menjalin hubungan dengan ibuku?". Beliau menjawab: "Ya, sambunglah silaturrahim dengannya Shahih Bukhari 2946."

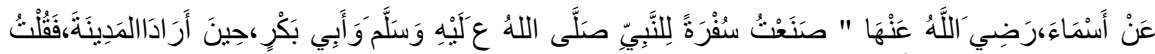

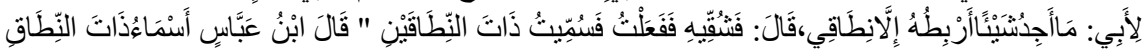
Asma' radliallahu 'anha berkata; Aku membuatkan bekal perjalanan untuk Nabi shallallahu 'alaihi wasallam dan Abu Bakar ketika keduanya hendak berangkat hijrah menuju Madinah. Aku katakan kepada bapakku; "Aku tidak mendapatkan sesuatu untuk mengikat melainkan kain ikat pinggangku".Bapakku berkata; "Potonglah kain ikat pinggang itu". Maka aku melakukannya. Dari situlah kemudian aku dijuluki dengan Dzatin Nithaqain (Wanita yang mempunyai dua potongan ikat pinggang)" Sedang Ibnu 'Abbas radliallahu 'anhuma berkata; "'Asma' adalah Dzatu Nithaq" (Shahih Bukhari no: 3617)

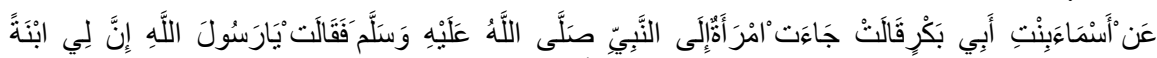

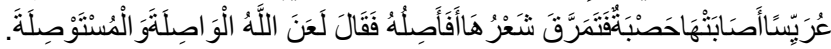

Asma' binti Abu Bakr ia berkata; Ada seorang wanita datang kepada Rasulullah shallallahu 'alaihi wasallam lalu dia berkata kepada beliau; "Aku mempunyai seorang anak gadis yang akan menjadi penganten mempelai. Dia terkena penyakit campak sehingga rambutnya gugur.Bolehkah aku sambung rambutnya?" Rasulullah shallallahu 'alaihi wasallam bersabda: 'Allah Ta'ala mengutuk orang yang menyambung rambut dan yang meminta supaya rambutnya disambung.' (Shahih Muslim no: 3961)

\section{2) Zainab binti Abi Salamah}

Namanya adalah Burrah binti Abi Salamah, kemudian diganti oleh Rasulullah menjadi Zainab. Dia dilahirkan di Habsyah.Zainab menjadi anak tiri Rasulullah sawsesudah ibunya yang bernama Ummi Salamah dinikahi oleh Rasulullah saw. 
Dia meriwayatkan hadis sebagian langsung dari Nabi saw, dan sebagian lagi melalui Aisyah binti Abi Bakr, Zainab binti Jahsy, Ummu Habibah binti Abi Sufyan. Dan yang meriwayatkan hadis darinya adalah: Puteranya: Abu Ubaidah ibn Abdillah ibn Zam'ah, Muhammad ibn Amr ibn A'tha, Humaid ibn Nafi'al Madani, 'Irak ibn Malik, 'Urwah ibn Zibair, Abu Salamah : Ibn Abdirrahman, Kulaib ibn Wail, Ali ibn al Husain Ibn Ali, Abu Qilabah al Jarami, dan lainnya.

Zainab termasuk sahabiyah yang banyak meriwayatkan hadis, hal tersebut disebabkan karena:

a. Dia dididik di keluarga Nabi, karena ibunya adalah isteri Nabi saw, karenanya dia mempunyai pengetahuan banyak tentang hadis nabi saw. Dan juga dia punya otorotas yang tinggi untuk periwayatan hadis.

b. Dia masih hadup sampai 6o tahun sesudah wafat Rasulullah saw, sehinga berkesempatan banyak untuk menyampaikan hadisnya.

Diantara hadis yang diriwayatkannya adalah:

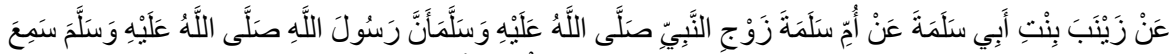

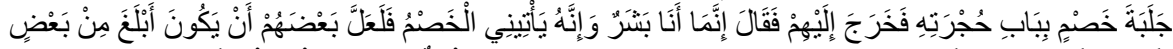

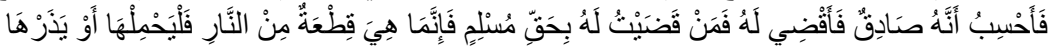
Zainab binti Abu Salamah dari Ummu Salamah isteri Nabi shallallahu 'alaihi wasallam, bahwa Rasulullah shallallahu 'alaihi wasallam mendengar suara orang yang sedang adu mulut di depan pintu kamar beliau, lalu beliau keluar menemui mereka seraya bersabda: "Aku ini hanya seorang manusia biasa, namun banyak orang yang membawa perkaranya kepadaku, sedangkan satu pihak di antara mereka ada yang lebih pandai berbicara sehingga aku mengira dialah yang benar, lalu kuputuskan dialah yang menang atas lawannya, oleh karena itu, siapa yang aku menangkan perkaranya di atas hak seorang muslim, sesungguhnya itu merupakan sepotong api dari neraka. Maka ia boleh membawanya atau meninggalkannya."(HR Muslim no: 3232)

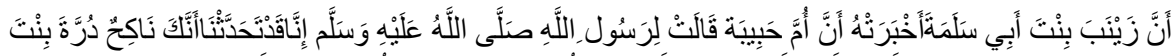

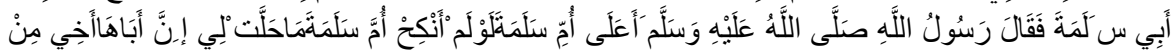

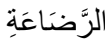

Zainab binti Abu Salamah Telah mengabarkan kepadanya bahwa Ummu Habibah berkata kepada Rasulullah shallallahu 'alaihi wasallam, "Kami telah berbincangbincang bahwa Anda ingin menikahi Durrah binti Abu Salamah." Maka Rasulullah shallallahu 'alaihi wasallam bersabda: "Apakah juga dengan menyatukan Ummu Salamah? Sekiranya aku tidak menikahi Ummu Salamah pun, maka ia juga tidak halal bagiku. Sesungguhnya bapaknya adalah saudara sesusuan denganku. (HR Bukhari no: 4729)". 
3) Nusaibah binti Kaab (Ummu Athiyah)

Nusaibah binti Kaab meriwayatkan hadis langsung dari Nabi saw. dan melalui Umar ibn Khattab. Orang -orang yang meriwayatkan hadis dari beliau adalah: Anas ibn Malik, Muhammad ibn Sirin, Hafshah binti Sirin, Abdul Malik ibn Umayr, Ismail ibn Abdirrahman ibn Athiyyah, Ali Ibn al Aqmar, dan Ummu Syarahil.

Nusaibah termasuk sahabt utama Rasulullah saw, meskipun dia bukankerabat Rasulullah, tetapi kifrahnya dalam pembelaan dan kesetiaan kepada Islam sangat besar, dia mengikuti perang bersama Rasulullah sebanyak tujuh kali. Dia banyak mengetahui Hadis-hadis Nabi. Setelah Rasulullah saw wafat, Nusaibah tinggal di Basrah dan disana dia menjadi sumber rujukan hadis-hadis Rasulullah saw.

Diantara hadis yang diriwayatkannya adalah:

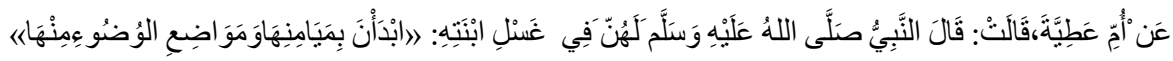
Telah menceritakan kepada kami Musaddad berkata, telah menceritakan kepada kami Isma'il berkata, telah menceritakan kepada kami Khalid dari Hafshah dari Ummu 'Athiyah berkata, "Nabi shallallahu 'alaihi wasallam bersabda kepada mereka saat memandikan puterinya: "Hendaklah kalian mulai dari yang sebelah kanan dan anggota wudlunya (HR Bukhari: 162)".

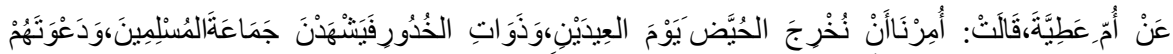

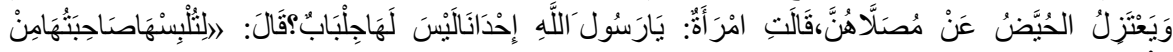

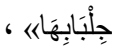

Ummu 'Athiyah berkata, "Kami diperintahkan untuk mengajak keluar (wanita) haid dan wanita yang sedang dipingit pada dua hari raya, sehingga mereka bisa menyaksikan jama'ah kaum Muslimin dan mendo'akan mereka, lalu menjauhkan wanita-wanita haid dari tempat shalat mereka."Seorang wanita lalu, "Wahai Rasulullah, di antara kami ada yang tidak memiliki jilbab?" Beliau menjawab: "Hendaklah temannya meminjamkan jilbab miliknya kepadanya." (Shahih Bukhari: 338)

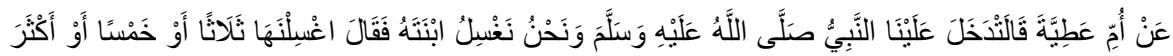

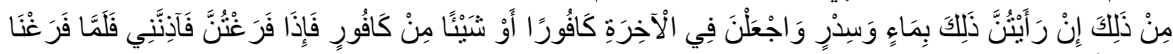

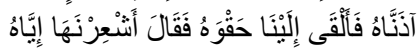
Ummu 'Athiyyah ia berkata; Rasulullah shallallahu 'alaihi wasallam masuk menemui kami yang sedang memandikan putrinya. Kemudian beliau pun bersabda: "Mandikanlah ia sebanyak tiga atau lima kali, atau pun lebih dari itu. Setelah itu, gunakanlah adukan air dan daun bidara.Sedangkan untuk siraman terakhir, gunakanlah kapur barus, atau sejenis kapur barus.Setelah selesai, beritahukanlah padaku." Setelah selesai memandikan, kami pun memberitahukan kepada beliau, dan beliau langsung memberikan kainnya pada kami dan bersabda: 
"Kenakanlah pada bagian bawah badannya. (Shahih Muslim: 1557)

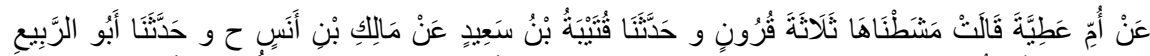

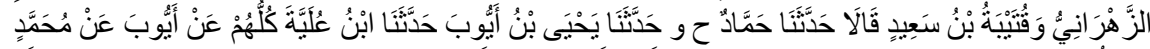

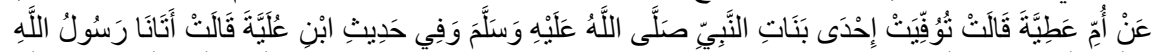

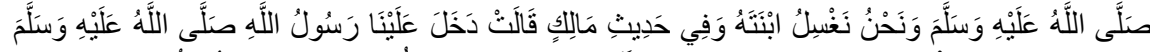

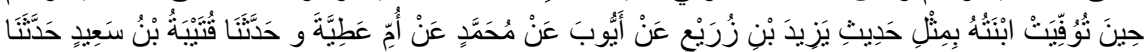

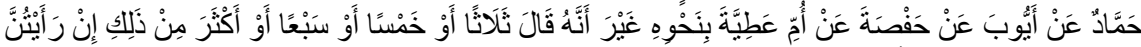

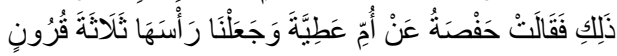

Ummu 'Athiyyah ia berkata; Rasulullah shallallahu 'alaihi wasallam masuk menemui kami yang sedang memandikan putrinya. Kemudian beliau pun bersabda: "Mandikanlah ia sebanyak tiga atau lima kali, atau pun lebih dari itu. Setelah itu, gunakanlah adukan air dan daun bidara. Sedangkan untuk siraman terakhir, gunakanlah kapur barus, atau sejenis kapur barus.Setelah selesai, beritahukanlah padaku." Setelah selesai memandikan, kami pun memberitahukan kepada beliau, dan beliau langsung memberikan kainnya pada kami dan bersabda: "Kenakanlah pada bagian bawah badannya." Dan telah menceritakan kepada kami Yahya bin Yahya telah mengabarkan kepada kami Yazid bin Zurai' dari Ayyub dari Muhammad bin Sirin dari Hafshah binti Sirin dari Ummu 'Athiyyah ia berkata, "Kami memintal rambutnya menjadi tiga." Dan telah menceritakan kepada kami Qutaibah bin Sa'id dari Malik bin Anas -dalam jalur lain- Telah menceritakan kepada kami Abu Rabi' Az Zahrani dan Qutaibah bin Sa'id keduanya berkata, telah menceritakan kepada kami Hammad -dalam jalur lain- Dan telah menceritakan kepada kami Yahya bin Ayyub telah menceritakan kepada kami Ibnu Ulayyah semuanya dari Ayyub dari Muhammad dari Ummu 'Athiyyah ia berkata; "Salah seorang putri Rasulullah shallallahu 'alaihi wasallam meninggal." Sementara di dalam hadits Ibnu Ulayyah; Rasulullah shallallahu 'alaihi wasallam datang menemui kami yang sedang memandikan mayit putrinya.Sedangkan di dalam haditsnya Malik; Rasulullah shallallahu 'alaihi wasallam masuk menemui kami saat anak putrinya meninggal. Serupa dengan hadits Yazid bin Zurai' dari Ayyub dari Muhamamd dari Ummu 'Atyiyyah. Dan menceritakan kepada kami Qutaibah bin Sa'id menceritakan kepada kami Hammad dari Ayyub dari Hafshah dari Ummu Athiyyah dengan hadits yang semisal, hanya saja ia mengatakan 'tiga kali atau lima kali atau tujuh kali atau lebih banyak dari itu. Maka Hafshah berkata dari Ummu 'Athiyah, "Dan kami memintal rambutnya menjadi tiga (HR Muslim: 1557)

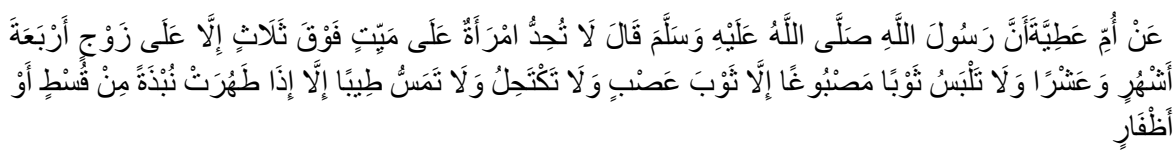
Ummu 'Athiyah bahwa Rasulullah shallallahu 'alaihi wasallam pernah bersabda: "Tidak boleh bagi seorang wanita melakukan ihdad karena kematian seseorang melebihi tiga hari, kecuali karena kematian suaminya yaitu empat bulan sepuluh 
hari, dan tidak boleh menggunakan pakaian yang berwarna warni, melainkan hanya memakai pakaian yang kasar (kain beludru), dan tidak boleh menggunakan celak mata, dan tidak boleh memakai wewangian kecuali jika masa iddahnya telah habis, maka diperbolehkan baginya memakai qusth dan adzfar (sejenis pohon yang harum baunya). (HR Muslim 2739)

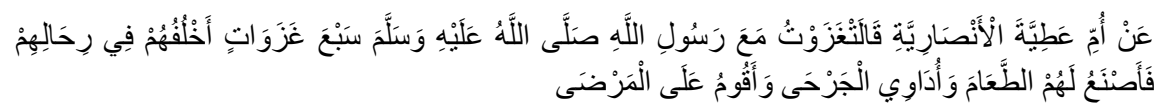
Ummu 'Athiyah Al Anshariyah dia berkata, "Aku pernah ikut berperang bersamasama dengan Rasulullah shallallahu 'alaihi wasallam sebanyak tujuh kali peperangan, aku tinggal di perkemahan mereka, memasak makanan untuk mereka, mengobati yang luka dan merawat orang-orang yang sakit."(HR Muslim: 3380)".

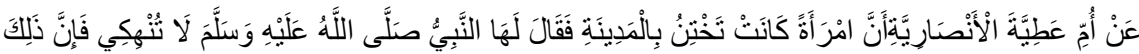

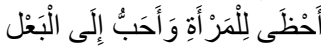

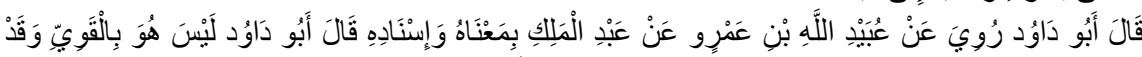

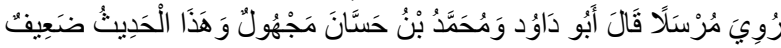
Ummu Athiyah Al Anshariyah berkata, "Sesungguhnya ada seorang permpuan di Madinah yang berkhitan, lalu Nabi shallallahu 'alaihi wasallam bersabda kepadanya: "Janganlah engkau habiskan semua, sebab hal itu akan mempercantik wanita dan disukai oleh suami." Abu Dawud berkata, "Diriwayatkan pula dari Ubaidullah bin Amru, dari Abdul Malik dengan sanad dan makna yang sama." Abu Dawud berkata, "Tetapi hadits ini tidak kuat, sebab ia diriwayatkan secara mursal." Abu Dawud berkata, "Muhammad bin Hassan adalah seorang yang majhul, sehingga hadits ini derajatnya lemah."(HR Abu Daud: 4587)

4) Fahithah binti Abi Thalib (Ummu Hani)

Dia adalah saudara perempuan Ali Ibn Abi Thalib. Saudara sepupu Rasulullah saw. Dia masuk Islam pada waktu Fath Makkah dan wafat pada masa pemerintahan Muawiyah (tahun $60 \mathrm{H}$ ).

Dia meriwayatkan hadis langsung dari Rasulullah saw. Dan yang meriwayatkan hadis darinya adalah: Pelayannya: Abu Murrah, Abu Shaleh Bazam, Cucu-cucunya: Ja'dah al makhzumy, Yahya ibn Ja'far, Harun dan Abdullah ibn lyyas, Suaminya: Hubayrah ibn Abi Wahab al Makhzumy

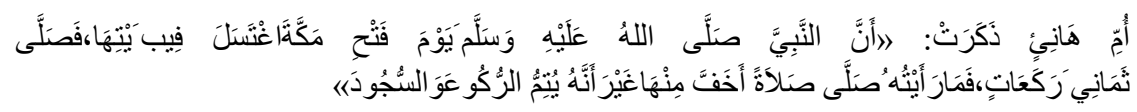

Telah menceritakan Ummu Hani", ialah yang menyebutkan bahwa beliau shallallahu 'alaihi wasallam pada hari penaklukan Makkah mandi di rumahnya 
kemudian shalat delapan rakaat. Kata Ummu Hani ", belum pernah kulihat beliau shalat lebih ringan daripadanya selain beliau menyempurnakan ruku' dan sujud. (Shahih Bukhari: 3954)

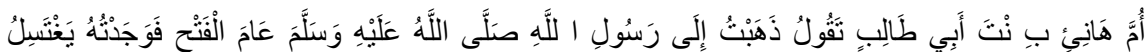

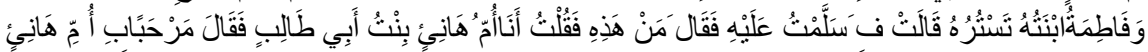

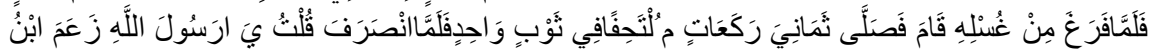

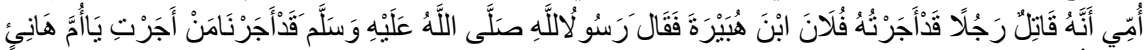

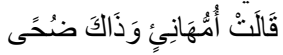

Ummu Hani' binti Abu Thalib berkata, "Aku berkunjung kepada Rasulullah shallallahu 'alaihi wasallam pada hari pembebasan Makkah, aku dapati beliau mandi sementara Fatimah, puteri beliau menutupinya dengan tabir." Ummu Hani' binti Abu Thalib berkata, "Aku lantas memberi salam kepada beliau, lalu beliau bertanya: "Siapakah ini?" Aku menjawab, "Aku Ummu Hani' binti Abu Thalib."Lalu beliau bertanya, "Selamat datang wahai Ummu Hani'."Setelah selesai mandi beliau shalat delapan rakaat dengan berselimut pada satu baju. Setelah selesai shalat aku berkata, "Wahai Rasulullah, anak ibuku mengatakan dia telah membunuh seseorang dan aku telah memberi ganti rugi kepada seseorang yakni Abu Hubairah." Maka Rasulullah shallallahu 'alaihi wasallam: "Kami telah setuju apa yang engkau berikan wahai Ummu Hani'!" Ummu Hani' berkata, "Saat itu adalah waktu dluha. (HR Bukhari: 344)

\section{5) Fathimah binti Qais}

Fathimah binti Qais ibn Kalid al Farasyiyyah al Fihrihiyyah dalah saudara Addahhak ibn Qais, ia adalah perempuan sahabiyah yang ikut berhijrah pada hijrah awal. Dia adalah perempuan yang cantik dam cerdas. Suaminya bernama Abu Bakar ibn Hafsh al Makhzumy, lalu bercerai dan kemudian menikah dengan Usamah ibn Zaid. Pada masa berikutnya dia bermukim di Kufah di tempat saudaranya yang menjadi amir di Kufah, dan meninggal disana.

Dia meriwayatkan hadis langsung dari Rasulullah saw. Hadis-hadisnya diriwayatkan oleh al Qasim ibn Muhammad ibn Abi Bakr, Abu Bakr ibn Abu al Jahm, Abu Salamah ibn Abdirrahman, Said ibn al Musayyab, Urwah ibn Zubayr, Abdullah ibn Abdillah ibn Ubayd ibn Mas'ud, Al Aswad ibn Yazid, Sulaiman ibn Yasar, Abdullah al Bahi, Muhammad ibn Abdirrahman ib Tsauban, Amir al Sya'bi dan yang lainnya.

Hadits yang diriwayatkan diantaranya:

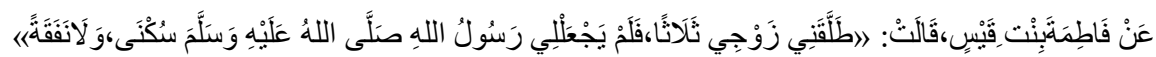
Shahih Muslim 2722: Dan telah menceritakan kepada kami Hasan bin Ali Al Hulwani telah menceritakan kepada kami Yahya bin Adam telah menceritakan kepada kami Hasan bin Shalih dari As Suddi dari Al Bahi dari Fathimah binti Qais 
dia berkata; Mantan suamiku pernah menceraikanku dengan talak tiga, kemudian Rasulullah shallallahu 'alaihi wasallam memutuskan bhawa saya tidak berhak mendapatkan tempat tinggal dan nafkah Shahih Muslim 2722

\section{6) Asma binti Yazid (Ummu salamah)}

Asma binti Yazid ibn al Sukan ibn Rafi' ibn al Imri I al Qais ibn Zaid ibn Abd al Asyhal al Anshariyah, dikenal denga Ummu Salamah atau Ummu Amir. Dia berbai'at kepada Rasulullah saw pada tahun pertama hijrah dan ikut serta dalam perang Yarmuk dan berhasil membunuh 7 orang tentara Rumawi. la dikenal sebagai juru bicara wanita, dan wfat pada tahun $30 \mathrm{H}$.

la meriwayatkah Hadis langsung dari Rasulullah saw. Orang-oran yang meriwayatkan hadis darinya adalah: Mahmud ibn Amr al Anshary, Muhajir ibn Abi Muslim, Syahr ibn Ausab dan yang lainnya.

Diantara Hadis yang diriwayatkannya adalah:

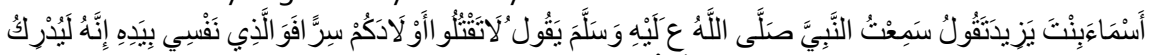

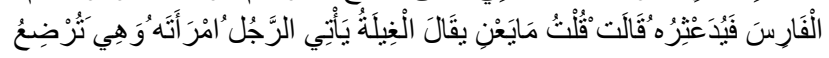

Asma' binti Yazid Al Anshariyah, berkata; aku mendengar Asma' binti Yazid berkata, "Aku mendengar Nabi shallallahu 'alaihi wasallambersabda: "Janganlah kalian membunuh anak-anak kalian dengan pembunuhan terselubung, demi Dzat yang jiwaku berada di tangan-Nya, sungguh itu telah dilakukan oleh orangorang Persi sehingga anak mereka menjadi lemah." Asma berkata, 'Aku berkata, 'Apa maksudnya?' Beliau bersabda: "Al Ghilah, yaitu seorang laki-laki mensetubuhi isterinya saat masih menyusui (Musnad Ahmad: 26303)

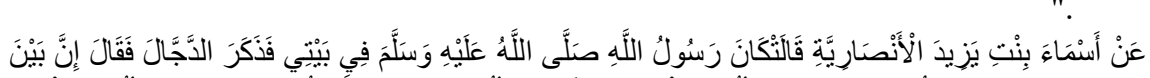

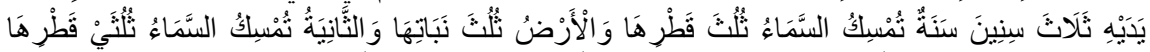

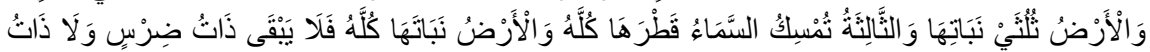

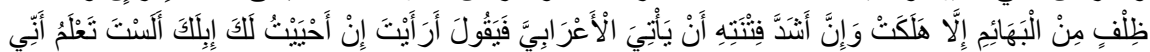

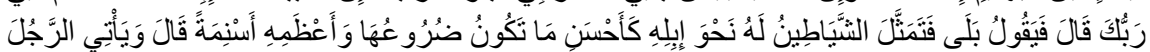

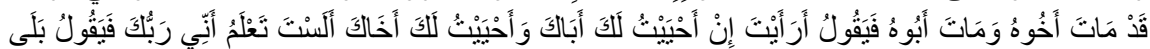

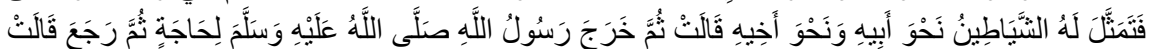

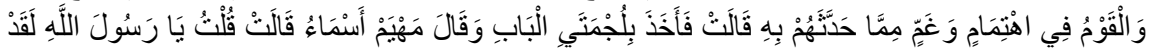

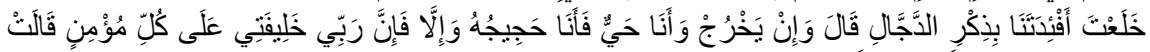

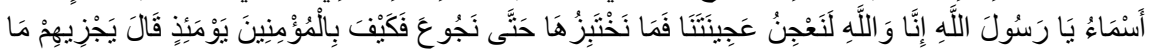

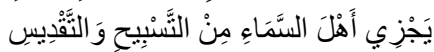

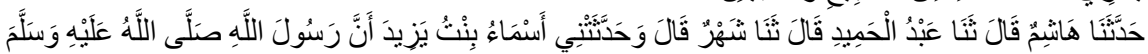

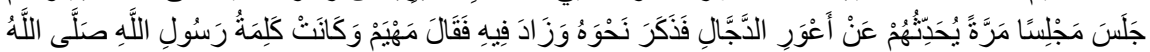

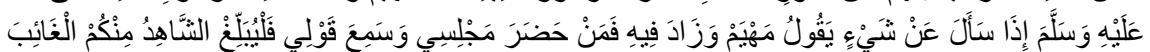

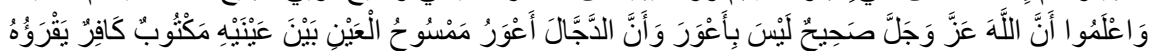

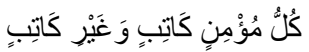

Asma' binti Yazid Al Anshariyah dia berkata, "Rasulullah shallallahu 'alaihi wasallam berada di dalam rumahku, kemudian beliau menyebutkan tentang 
Dajjal, beliau bersabda: "Sungguh, menjelang datangnya Dajjal akan ada tiga tahun (masa sulit); tahun pertama, langit akan menahan sepertiga dari air hujannya dan bumi menahan sepertiga dari tumbuh-tumbuhannya, tahun kedua langit akan menahan dua pertiga dari air hujannya dan bumi akan menahan dua pertiga dari tumbuh-tumbuhannya, dan pada tahun yang ketiga langit akan menahan air hujannya semuanya dan bumi juga akan menahan tumbuhtumbuhannya semuanya, maka tidak ada lagi tersisa yang memiliki Khuf atau kaki (telapak kaki hewan berkaki empat) kecuali akan binasa. Dan yang paling dahsyat dari fitnah dajjal adalah seperti, ketika seorang badui datang kepadanya, Dajjal berkata, 'Bagaimana pendapatmu jika aku bangkitkan untamu dengan susu yang besar dan punuknya besar, apakah kamu mengakui bahwa aku adalah Rabbmu?' badui itu menjawab, 'Ya'. Lalu setan berubah bentuk menyerupai untanya dan mengikutinya.Kemudian Dajjal berkata kepada orang tadi, 'Bagaimana pendapatmu jika aku bengkitkan bapak dan anakmu, dan siapa yang kamu ketahui dari keluargamu, apakah mengakui bahwa aku adalah Rabbmu? maka badui tersebut menjawab, 'Ya'. Maka setan berubah bentuk seperti keluarganya dan mengikutinya." Kemudian Rasulullah shallallahu 'alaihi wasallam keluar untuk suatu keperluan, ketika kembali orang-orang masih termangu dan sedih dengan apa yang baru saja beliau ceritakan kepada mereka." Asma berkata, "Kemudian beliau meraih dua daun pintu seraya bersabda: "Wahai Asma, bagaimana kabarmu?" Asma berkata, "Aku lalu menjawab, "Wahai Rasulullah, engkau telah membuat hati kami copot karena cerita Dajjal." Beliau lalu bersabda: "Jika Dajjal keluar dan aku masih bersama kalian maka aku yang akan melawannya, jika tidak maka Rabbku lah yang akan menggantikan aku untuk menjaga setiap Mukmin." Asma berkata, "Wahai Rasulullah, sungguh, kami telah membuat adonan, namun susah untuk menjadi roti hingga kami lapar! Lalu bagaimana dengan kondisi kaum Mukminin saat itu?" Beliau menjawab: "Cukuplah bagi mereka sebagaimana penduduk langit; bertasbih dan bertaqdis (mensucikan Allah)." Telah menceritakan kepada kami Hasyim berkata; telah menceritakan kepada kami Abdul Hamid berkata; telah menceritakan kepada kami Syahr berkata; dan telah menceritakan kepadaku Asma binti Yazid bahwa Rasulullah shallallahu 'alaihi wasallam suatu ketika duduk dalam sebuah majlis, beliau menceritakan kepada para sahabat tentang Dajjal...lalu ia menyebutkan seperti hadits tersebut. Hanya saja ia menambahkan, Beliau bersabda: "Mahyam (Apa kabarmu)." Ini adalah kalimat yang biasa beliau gunakan untuk bertanya tentang sesuatu, beliau katakan 'Mahyam'. Kemudian ia tambahkan; (beliau bersabda): "Barangsiapa menghadiri majlisku dan mendengar perkataanku, maka hendaklah orang yang hadir menyampaikan kepada orang yang tidak hadir dari kalian. Ketahuilah, sesungguhnya Allah itu sempurna dan tidak juling, sementara Dajjal adalah seorang yang juling. Di antara kedua matanya tertulis 'kafir', setiap orang mukmin akan dapat membacanya, baik ia bisa baca tulis atau pun buta aksara Musnad Ahmad :26298) 


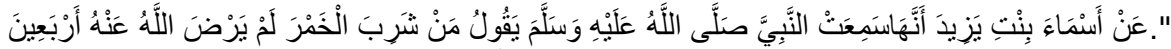

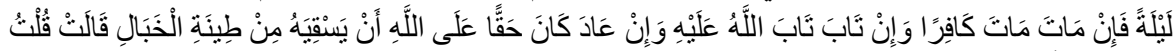

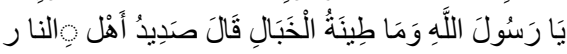

Telah menceritakanAsma' binti Yazid bahwa dia telah mendengar Nabi shallallahu 'alaihi wasallam bersabda "Barangsiapa meminum khamer, maka Allah tidak akan ridla kepadanya selama empat puluh malam, jika dia mati maka ia mati dalam keadaan kafir.Namun jika dia bertaubat, maka Allah akan memberinya taubat, jika ia mengulangi, maka menjadi hak Allah untuk menyiramnya dengan Thinatul Khabal."Asma' berkata, "Aku bertanya, "Wahai Rasulullah apa itu Thinatul Khabal?" beliau menjawab: "Nanahnya penghuni neraka."(Musnad Ahmad: 26321)

\section{Simpulan}

Perempuan shahabiyah sangat berperan dalam meriwayatkan hadishadis Rasulullah saw, baik secara langsung dari Rasulullah saw, ataupun melalui para sahabat, baik dari sahabat laki-laki maupun sahabat sesama perempuan.

Para perempuan sahabiyah sangat aktif dalam mengajarkan, merwayatkan hadis-hadis Rasulullah saw, ketika ditanya ataupun tidak ditanya. Materi hadis yang mereka riwayatkan cukup banyak dan bervariasi, baik hadis yang menyangkut permasalahan keimanan dan keislaman secara umum, masalah muamalah, terutama hal-hal yang berkaitan dengan masalah keluarga, kehidupan rumah tangga seperti: khitbah, nikah, thalak, pergaulan suami isteri, perlakuan kepada anak anak, dan hal-hal yang sangat erat dengan perempuan dan keluarga seperti wudhu, mandi, haid, thalak, nifas, iddah, dan lain lain.

\section{Referensi}

Abdurrahman. 2009. Studi Kitab Hadis. Jogyakarta: Teras

Abi 'Abdillah Muhammad bin Zaid Al-Qazwini (Ibnu Majah). Sunan Ibnu Majah, cetakan Agus Solahudin. Ulumul Hadist. Bandung: CV. Pustaka Setia Maktabah Al-Ma'arif, Riyadh. Ajaj Al-Khathib,As-Sunnah Qabla At-Tadwin, cetakan Maktabah Wahbah, Kairo

Al-Hafizh Ibnu Hajar Al-'Asqalani, Fathul Bari bi Syarh Shahih Bukhari, cetakan Darul Hadits, Kairo.

Al-Hafizh Ibnu Hajar Al-Asqalan Taqribut Tahdzib, cetakan Baitul Afkar Ad-Dauliyyah, Riyadh.

Asqalani, Syihab al din Abu al Fadl Ahmad ibnu Ali. 1994. Tahzib al Tahzib, Beirut, Dar al kutubil Ilmiyah

Azra, azyumardi. 1993. Peranan Hadis dalam Perkembangan Historical Awal Islam dalam al hikmah.

Darul Kutub Al-'llmiyyah, Beirut

Hanbal, Ahmad ibnu, Musnad Ahmad Ibn Hanbal, Bairut Darul Fikr, tt

Hasbi Ashshiddiqy. 1981. Pokok-pokok Dirayah Ilmu Hadis. Jakarta: Bulan Bintang . 1981. Sejarah \&Pengantar Ilmu Hadits. Jakarta: Bulan Bintang

Imam Abi Al-Husain Muslim bin Al-Hajjaj Al-Qusyairi An-Naisaburi Shahih Muslim, cetakan Imam Abi Al-Husain Muslim bin Al-Hajjaj Al-Qusyairi An-Naisaburi. Shahih Muslim cetakan Darul Kutub Al-'Ilmiyyah, Beirut.

Jalaluddin As-Suyuthi, Tadribur Rawi, Daar Thaybah, Riyadh.

Kasman. 2012. Hadist Dalam Pandangan Muhammadiyah. Yogyakarta: Penerbit Mitra 
Pustaka

M.M Azami. Studies In Early hadits Literature. Alih bahasa: Ali Musthafa Ya,qub, Hadis Mahmud Ath-Thahhan. Taisir Musthalahul Hadits. Maktabah Al-Ma'arif, Riyadh. 1978. Ushul al Takhrij wa dirasat al asanid, Beirut, Dar Al Qur an al Karim

Muhammad Alawi al Maliki, Almanhalu al Lathiffi ushulil Hadits asyarif, alih bahasa Adnan Muhammad ibn Ali Asysyaukani. Al Fawaid al majmu'ah fi ahaditsil maudluah, dar Kutub al ilmiyah, Bairut, Libanon

Muhammad Nashiruddin Al-Albani. Silsilah Al-Ahadits Adh-Dha'ifah wal Maudhu'ah cetakan. Maktabah Al-Ma'arif, Riyadh

Mushthafa As-Siba'i As-Sunnah wa Makanatuha fit Tasyri' Al-Islami, cetakan Al-Maktab AlIslami, Damaskus.

Musthafa Zahri. 1981. Kunci memahami Musthalah Hadits. Bina Ilmu Surabaya

Nabawi dan sejarah Kodifikasinya. 1994. Pustaka Firdaus Jakarta

Nurrudin. 2012. Ulumul Hadis Cetakan pertama. Bandung: PT Remaja Rosdakarya

Qahar. 2012. Ilmu Ushul Hadits. Yogyakarta: Pustaka Pelajar

Syuhudi Ismail. Pengantar Ilmu Hadits. Bandung: Angkasa 1992. Metodologi penelitian Hadis Nabi. Jakarta: Bulan Bintang 1988. Kaedah Kesahihan Sanad Hadis. Jakarta: Bulan Bintang 1991. Cara Praktis Mencari Hadits. Jakarta: Bulan Bintang

Suryadi cs. 2009. Metolologi Penelitian Hadis. Yogyakarta: Teras 